\title{
Analisis Produksi Dan Pendapatan Usahatani Padi Sawah Di Desa Manleten Kecamatan Tasifeto Timur Kabupaten Belu
}

Terezina Lopez ${ }^{\mathrm{a}}$, dan Yosefina Marice Fallo ${ }^{\mathrm{b}}$

${ }^{a}$ Fakultas Pertanian, Universitas Timor, Kefamenanu, TTU - NTT, Indonesia. Email : terezinalopes93@gmail.com

${ }^{b}$ Fakultas Pertanian, Universitas Timor, Kefamenanu, TTU - NTT, Indonesia. Email : yosefinamaricefallo@ gmail.com

\section{Article Info}

Article history:

Received 8 Desember 2018

Received in revised form 11 Desember 2018

Accepted 21 Januari 2019

DOI:

https://doi.org/10.32938/ag.v4i01.616

\section{Keywords:}

Produksi

Pendapatan

Usahatani

\section{Abstrak}

Penelitian ini bertujuan: 1) Mengetahui gambaran umum usahatani padi sawah di Desa Manleten Kecamatan Tasifeto Timur Kabupaten Belu; 2) Mengetahui pendapatan usahatani padi sawah di Desa Manleten Kecamatan Tasifeto Timur Kabupaten Belu. Penelitian ini telah dilaksanakan di Desa Manleten Kecamatan Tasifeto Timur Kabupaten Belu sejak bulan Januari sampai bulan September 2018. Metode yang digunakan dalam penelitian ini adalah metode survei dengan jenis data yang digunakan data primer dan data sekunder, untuk mengetahui tujuan pertama digunakan analisis deskriptif, sedangkan untuk mengetahui pendapatan usahatani padi sawah yaitu selisih antara penerimaan dan semua biaya. Hasil penelitian menunjukkan bahwa kegiatan usahatani padi sawah melalui beberapa tahapan: 1) persemaian; 2) persiapan dan pengolahan lahan sawah; 3) penanaman; 4) pemeliharaan; 5) panen; 6) pasca panen; dan 7) pemasaran. Penerimaan usahatani padi sawah di Desa Manleten berkisar antara Rp 18.000.000 sampai dengan Rp 137.500.000 dengan rata-rata Rp 57.889.063 biaya produksi usahatani padi sawah berkisar antara $\mathrm{Rp} 495.470$ sampai dengan $\mathrm{Rp} 24.757 .700$ dengan rata-rata sebesar $\mathrm{Rp}$ 12.696.538 pendapatan usahatani padi sawah juga berkisar antara Rp 1.820.667 sampai dengan Rp 113.774 .000 dengan rata-rata sebesar Rp 45.192.524.

\section{Pendahuluan}

\subsection{Latar Belakang.}

Padi merupakan salah satu komoditi yang mempunyai prospek cerah guna menambah pendapatan para petani. Hal tersebut dapat memberi motivas tersendiri bagi petani untuk lebih mengembangkan dan meningkatkan produksinya dengan harapan agar pada saat panen dalam kenyataannya berbicara lain. Ketika saat panen tiba, hasil melimpah tetapi harga mendadak turun, dan lebih parah lagi jika hasil produksi yang telah diprediksikan jauh melenceng dari jumlah produksi yang dihasilkan, produksi minim, harga rendah dan tidak menentu membuat petani padi kadang merasa kecewa bahkan patah semangat untuk tetap mengembangkan usaha pertaniannya

Produksi padi sawah di Kecamatan Tasifeto Timur selama tiga tahun terakhir mengalami peningkatan hal ini dapat dilihat dari jumlah produksi padi sawah di Kecamatan Tasifeto Timur selama tahun 2014 sampai tahun 2016 (Dinas Pertanian Kab. Belu 2016)

Tabel 1.Luas Panen, Produksi, dan Produktivitas Komoditi Padi Sawah di Desa Manleten

\begin{tabular}{cccc}
\hline Tahun & $\begin{array}{c}\text { Luas Panen } \\
(\mathrm{Ha})\end{array}$ & $\begin{array}{c}\text { Produktivitas } \\
(\text { Ton/Ha })\end{array}$ & $\begin{array}{c}\text { Produksi } \\
\text { (Ton) }\end{array}$ \\
\hline 2014 & 350 & 3 & 1050 \\
2015 & 360 & 5 & 1800 \\
2016 & 360 & 6 & 2160 \\
\hline
\end{tabular}

Sumber : Desa Manleten 2016

Gambaran usahatani padi sawah terdiri dari persemaian, persiapan dan pengolahan lahan sawah, penanaman, pemeliharaan, panen, pasca panen dan pemasaran. Jenis benih yang digunakan oleh petani di Desa Manleten Kecamatan Tasifeto Timur Kabupaten Belu umumnya petani menggunakan bibit padi yang disiapkan dari musim tanam sebelumnya. Petani di Desa Manleten Kecamatan Tasifeto Timur Kabupaten Belu biasanya tidak melakukan perendaman bibi tetapi mereka langsung melakukan penaburan. Pembajakan, penggaruan, kegiatan membalik tanah dengan menggunakan traktor nilai sewa sebesar Rp 15.000/are dan rontok dengan menggunakan tenaga mesin/metode mekanik, dan ditambah biaya bahan bakar. Penanaman biasanya dilakukan oleh beberapa orang yang berasal dari dalam keluarga maupun dari luar keluarga. Upah yang dibayarkan petani kepada tenaga kerja luar sebesar Rp 50.000/hari. Untuk penyiangan gulma dan pengendalian hama menggunakan metode kimiawi. Penelitian ini bertujuan untuk mengetahui gambaran umum usaha tani dan pendapatan usaha tani padi sawah di Desa Manleten Kecamatan Tasifeto Timu Kabupaten Belu.

\section{Metode}

Penelitian ini dilaksanakan di Desa Manleten Kecamatan Tasifeto Timu Kabupaten Belu. Waktu penelitian pada Januari - September tahun 2018. Penelitian ini dilakukan dengan metode survei, data yang digunakan dalam penelitian ini adalah data primer dan data sekunder. Pengambilan sampe menggunakan random sampling secara acak sederhana dengan jumlah $15 \%$ Dengan demikian sampel dalam penelitian ini berjumlah 32 responden.

Analisis data yang digunakan analisis deskriptif dan analisis pendapatan (Soekartawi, 2006). Besar pendapatan usahatani padi sawah dapat dihitung dengan rumus sebagai berikut :

$I=$ Total Revenue - Total Cost $\ldots \ldots \ldots \ldots \ldots \ldots \ldots \ldots \ldots \ldots \ldots \ldots \ldots \ldots$. Dimana:

I $\quad$ Income (Pendapatan usahatani)

$\mathrm{TR} \quad=$ Total revenue $($ Total penerimaan $)$

TC $\quad=$ Total $\operatorname{cost}$ (Total biaya) (Mubyarto, 2003).
Besar biaya total usahatani padi sawah dapat dihitung dengan rumus sebaga berikut :

Total Cost $=$ Total Fixed Cost + Total Variable Cost.

Dimana:

TC = Biaya total

TFC = Total biaya tetap

TVC = Total biaya variabel (Sudarsono, 2008) berikut :

Besar penerimaan total usahatani padi sawah dapat dihitung dengan rumus

TR = P. $Q$

TR = Penerimaan

$\mathrm{P} \quad$ = Harga produk.

Q = Jumlah produksi (Sukirno, 2005)

\section{Hasil dan Pembahasan}

a. Gambaran Wilayah Penelitian

- Letak dan Luas Daerah

Desa Manleten terdiri dari 11 Dusun dan 24 RT yang terletak pada wilayah administrasi Kecamatan Tasifeto Timur, mempunyai luas wilayah $40 \mathrm{Km}^{2}$ dengan ketinggian $\pm 450 \mathrm{mdpl}$. Batas wilayah adalah sebagai berikut : Sebelah Utara berbatas dengan Desa Umaklaran; Sebelah Timur berbatas dengan Desa Halimodok; Sebelah selatan berbatas dengan Desa Fatuba'a; dan Sebelah Barat berbatas dengan kelurahan Fatubenao.

\section{- Identitas Responden}

Usia yang produktif tentu akan memberikan kemudahan dalam mengusahakan usahatani padi sawah. Jika umur petani semakin tua maka akan berpengaruh pada kemampuan petani tersebut. Umur menurut tingka produktifitasnya terbagi atas 3 yakni usia belum produktif, usia produktif dan usia tidak produktif.

Tabel 2. Kelompok Umur Responden Petani Padi Sawah di Desa Manleten

\begin{tabular}{ccc}
\hline Kelompok Umur (Tahun) & Jumlah Responden (Jiwa) & Persentase $\%$ \\
\hline $31-40$ & 2 & 6,250 \\
$41-50$ & 2 & 6,250 \\
$51-60$ & 16 & 50,000 \\
$61-70$ & 10 & 31,250 \\
$71-80$ & 2 & 6,250 \\
\hline Jumlah & 32 & 100 \\
\hline
\end{tabular}

Sumber : Desa Manleten 2016

Berdasarkan Tabel 2 dapat diketahui bahwa kelompok umur petani yang mengusahakan padi sawah terbanyak berada pada kelompok umur 51-60 tahun, jumlah responden 16 orang dengan persentase $50 \%$. Hasil wawancara responden, tingkat pendidikan formal dari Sekolah Dasar (SD) sampai dengan Sekolah Menengah Atas (SMA) dapat dilihat pada tabel di bawah.

Tabel 3. Kelompok Pendidikan Petani Responden Padi Sawah di Desa Manleten

\begin{tabular}{ccc}
\hline Jenjang Pendidikan & Jumlah (Orang) & Persentase $\%$ \\
\hline Tidak sekolah & 6 & 18,750 \\
SD & 16 & 50,000 \\
SMP & 5 & 15,625 \\
SMA & 3 & 9,375 \\
SARJANA & 2 & 6,250 \\
\hline Jumlah & 32 & 100,000 \\
\hline
\end{tabular}

Sumber : Desa Manleten 2016 
Berdasarkan Tabel 3 dapat diketahui bahwa kelompok pendidikan petani terbesar terdapat pada jenjang pendidikan Sekolah Dasar (SD) dengan jumlah 16 responden $(50 \%)$. Pengalaman petani selama berusahatani padi sawah yang berkisar antara 5-50 tahun. Tingkat pengalaman usahatani responden dapat dilihat pada tabel berikut.

Tabel 4. Pengalaman Petani Responden Padi Sawah di Desa Manleten

Kelompok Pengalaman Jumlah Responden

\begin{tabular}{ccc} 
(Tahun) & $($ Orang) & Persentase $(\%)$ \\
\hline $1-10$ & 7 & 21,875 \\
$11-20$ & 17 & 53,125 \\
$21-30$ & 7 & 21,875 \\
$31-40$ & 0 & 0 \\
$41-50$ & 1 & 3,125 \\
\hline Jumlah & 32 & 100 \\
\hline
\end{tabular}

Sumber : Desa Manleten 2016

Berdasarkan Tabel 4, dapat diketahui bahwa kelompok pengalaman usahatani terbesar terdapat pada 11-20 tahun, sebanyak 17 responden dengan persentase $53,125 \%$.

Jumlah tanggungan keluarga petani responden usahatani padi sawah dapat dilihat pada tabel berikut.

Tabel 5. Tanggungan Keluarga Responden Padi Sawah di Desa Manleten

\begin{tabular}{ccc}
\hline Tanggungan Keluarga (Orang) & Jumlah Responden & Persentase \% \\
\hline $01-05$ & 22 & 68,750 \\
$06-10$ & 10 & 31,250 \\
\hline Jumlah & 32 & 100 \\
\hline
\end{tabular}

Sumber : Desa Manleten 2016

Berdasarkan Tabel 5 dapat diketahui bahwa jumlah tanggungan keluarga terbanyak terdapat pada kisaran 1-5 orang dengan persentase sebesar $65,116 \%$ responden.

\section{- Penggunaan Lahan}

Lahan yang digunakan untuk usahatani padi sawah adalah lahan milik sendiri dengan luas bervariasi antara 13-200 are. Tabel 6 menjelaskan bahwa responden berusahatani padi sawah terbanyak seluas 51-100 are sebanyak 18 orang dengan persentase $56,250 \%$. Petani responden yang menggunakan lahan 20-50 are sebanyak 7 orang dengan persentase sebesar $21,875 \%$. Petani responden yang menggunakan lahan 101-150 sebanyak 2 orang dengan persentase $6,250 \%$, sedangkan yang menggunakan lahan 151-200 sebanyak 5 orang dengan persentase $15,625 \%$.

Tabel 6. Luas Penggunaan Lahan Usahatani Padi Sawah di Desa Manleten

\begin{tabular}{ccc}
\hline Kelompok luas lahan (are) & Jumlah (orang) & Persentase \% \\
\hline $20-50$ & 7 & 21,875 \\
$51-100$ & 18 & 56,250 \\
$101-150$ & 2 & 6,250 \\
$151-200$ & 5 & 15,625 \\
\hline Jumlah & 32 & 100,000 \\
\hline
\end{tabular}

Sumber : Desa Manleten 2016

\section{b. Gambaran Usahatani Padi Sawah di Desa Manleten}

Aktivitas usahatani padi sawah yang dilakukan oleh petani di Desa Manleten Kecamatan Tasifeto Timur Kabupaten Belu meliputi: persiapan benih, pengolahan lahan calon persemaian, penaburan benih, pemeliharaan persemaian, pembersihan lahan sawah, pembajakan, penggaruan, penanaman, penyulaman, penyiangan gulma, pengairan, pengendalian pestisida, pemupukan, panen (perontokan), dan pasca panen (pengangkutan, pengeringan, penggilingan) dan pemasaran.

\section{- Persemaian}

\section{Persiapan bibit (penggunaan bibit).}

Jenis benih yang selama ini digunakan bibit padi yang disiapkan dari musim tanam sebelumnya. Petani biasanya tidak melakukan perendaman bibit tetapi mereka langsung melakukan penaburan. Varietas bibit yang biasa digunakan berupa Nona kupang, IR, IR 64, IR 4, Inpadi 6, Inpadi 8, Inpadi 33, Mapan, Membramo, dan Ceheran. Alat yang digunakan dalam persiapan bibit berupa karung.

\section{Pengolahan lahan persemaian.}

Persemaian dilakukan di dalam persawahan dan ada juga petani yang melakukan tempat persemaian di luar persawahan. Pengolahan lahan untuk persemaian ini dilakukan dengan cara pencangkulan hingga tanah menjadi lumpur dan tidak lagi terdapat gumpalan tanah. Lahan yang sudah halus lumpurnya ini kemudian dipetak-petak dan antara petak-petak tersebut dibuat parit untuk mempernudah pengaturan air. Alat yang digunakan oleh petani berupa cangkul, parang dan tajak.

\section{Penaburan benih}

Bibit yang telah disiapkan, ditabur ditempat persemaian yang telah diolah Petani melakukan penaburan bibit secara teliti, merata dan tipis agar benih padi tumbuh tidak saling bertumpukan. Kemudian, dilakukan penutupan benih menggunakan daun. Penaburan benih ini biasanya menggunakan alat seperti karung, ember dan piring.

\section{Pemeliharaan persemaian}

Bagi petani yang melakukan tempat persemaian di luar persawahan maka mereka menyiram benih sehari sekali. Pemupukan benih padi yang telah disemaikan dilakukan kira-kira pada umur 1 MST. Pupuk yang digunakan yaitu Urea. Pemeliharaan benih ini dilakukan agar benih bisa tumbuh dengan subur sesuai dengan yang diinginkan oleh petani.

\section{- Persiapan dan Pengolahan Lahan Sawah}

\section{Pembersihan lahan sawah}

Pematang sawah dibersihkan dari rerumputan, dan membuat benteng untuk menahan air selama pengolahan tanah agar tidak mengalir keluar dari petakan. Saluran diperbaiki dan dibersihkan dari rerumputan agar dapat memperlancar arus air yang masuk ke dalam petakan. Sisa jerami dan sisa tanaman di dalam persawahan dibersihkan sebelum tanah diolah, jerami tersebut dibakar. Pembersihan sisa-sisa tanaman, memasukan air ke dalam persawahan dan perbaikan pematang yang rusak dilakukan satu minggu sebelum melakukan pembajakan. Kegiatan ini tidak mengeluarkan biaya karena dapat dikerjakan oleh tenaga kerja dalam keluarga. Pembersihan lahan sawah menggunakan cangkul, sabit dan parang.

\section{Pengolahan Lahan}

Pembajakan yaitu kegiatan membalik tanah dengan menggunakan traktor / tenaga mesin, dengan nilai sewa sebesar Rp15.000/are dan di tambah biaya minyak. Pembajakan ini dilakukan untuk memberantas gulma, karena dengan pembajakan tumbuhan dan biji gulma akan terbenam.

Penggaruan dilakukan untuk meleburkan gumpalan tanah sampai melumpur dan meratakan permukaan petak sawah. kegiatan pengolahan lahan dilakukan setelah satu minggu sampai satu minggu lebih dilakukan persemaian dan siap ditanami setelah 2-6 hari kegiatan pengolahan lahan selesai. Pembajakan dan penggaruan para petani di Desa Manleten Kecamatan Tasifeto Timur Kabupaten Belu menyewa tenaga mesin, dengan nilai sewa sebesar Rp15.000/are.

\section{Penanaman}

Penanaman padi dilakukan ketika bibit telah mencapai umur tanam 20-30 hari, 5-7 berdaun helai, jumlah bibit yang ditanam biasanya 3-4 bibit sehingga jarak tanamnya tidak menentu dan lahan sawah telah disiapkan. Benih setelah di cabut biasanya diikat dengan menggunakan alang-alang. Ada petani yang menanam padi menggunakan barisan dan ada yang tidak menggunakan barisan. Petani yang menanam secara barisan menggunakan tali rafia dan kayu. Penanaman biasanya dilakukan oleh beberapa orang baik berasal dari dalam keluarga maupun dari luar keluarga dengan sistem upah. Upah yang dibayarkan petani kepada tenaga kerja luar keluarga sebesar Rp50.000/hari/orang.

\section{- Pemeliharaan}

Pemeliharaan yang dilakukan oleh petani di Desa Manleten kecamatan Tasifeto Timur Kabupaten Belu diantaranya sebagai berikut :

\section{Penyulaman}

Penyulaman yaitu kegiatan menggantikan benih padi yang layu, mati dan di makan oleh keong dengan benih padi yang baru dicabut dan pindahkan dari tempat persemaian. Penyulaman ini dilakukan 2-3 kali pada saat tanaman berumur 1-5 hari. Penyulaman ini hanya dilakukan oleh tenaga kerja dalam keluarga.

\section{Penyiangan gulma}

Penyiangan gulma dilakukan untuk mengurangi atau membersihkan gulmagulma yang merupakan pengganggu tanaman padi. Kegiatan penyiangan gulma yang dilakukan di tempat penelitian biasanya dilakukan dengan cara di semprot dengan menggunakan alat semprot yaitu hand sprayer, knapsack sprayer dan gayung. Petani di desa manleten biasanya melakukan penyiangan gulma setelah pemupukan

\section{Pengairan}

Pengairan merupakan salah satu faktor yang sangat penting bagi usahatani padi sawah, sistem pengairan yang ada di Desa Manleten Kecamatan Tasifeto Timur Kabupaten Belu yaitu menggunakan irigasi yang sumber airnya berasal dari bendungan dan dialirkan melalui selokan-selokan atau saluran yang menuju lahan sawah.

\section{Pengendalian Hama}

Pengendalian hama dan penyakit merupakan tindakan yang perlu dilakukan untuk melindungi tanaman padi dari kerusakan yang ditimbulkannya. Akibat serangan hama dan penyakit dapat menurunkan produksi padi sawah. hama dan penyakit di daerah penelitian yang sering mengganggu tanaman padi sawah yakni hama wereng, hama walang sengit, hama belalang, hama keong dan hama tikus, sedangkan penyakit yang sering muncul busuk akar dan busuk batang. Pestisida yang sering digunakan yaitu keong tox, lugen, agen, indodan, akodan, bassa, bestronoid, sandrowith, cix, icon, sidametrin, superflora, rusben, gibro, indomin, brantas, nakuacron, kiltop, nalate, klensect, dan penalty. Alat yang digunakan dalam pengendalian hama dan penyakit berupa hand sprayer knapsack sprayer dan gayung.

\section{Pemupukan}

Pemupukan merupakan proses menambahkan hara pada tanaman padi, pemupukan yang dilakukan di Desa Manleten Kecamatan Tasifeto Timur Kabupaten Belu sebanyak 2 kali, pada saat tanaman padi berumur 3-5 hari dan pada saat tanaman berumur 60-an hari. Pemupukan dilakukan dengan cara di 
hambur. Alat yang digunakan karung, ember dan gayung. Jika tanaman padi yang berlebihan pupuk atau kekurangan pupuk maka tanaman padi akan kelihatan kekuning-kuningan. Pupuk yang digunakan petani ditempat penelitian yakni Urea, $\mathrm{KCl}$ dan $\mathrm{Sp} 36$.

\section{Panen dan Pasca Panen \\ $\circ \quad$ Panen}

Kegiatan pemanenan dapat dilakukan ketika sudah terlihat tanda-tanda seperti bulir mulai menguning, seluruh daun mengering, gabah sudah keras dan sudah kering. Panen dilakukan pada saat tanaman berumur 3-4 bulan, tergantung pada varietas yang digunakan. proses pemanenan yang dilakukan di Desa Manleten Kecamatan Tasifeto Timur Kabupaten Belu yaitu di potong dengan menggunakan sabit, dan pengangkutan dari dalam sawah ketempat perontokan dengan cara padi yang sudah di potong diikat dengan tali gewang atau karung dibagi dua dan taruh di karung tersebut lalu angkat (dipikul). Alat-alat yang digunakan dalam perontokan: terpal, mesin rontok, karung, tali gewang, sabit dan ember / sahara. Kegiatan perontokan dapat dilakukan oleh tenaga kerja baik dari dalam keluarga maupun dari luar keluarga, kalau luar keluarga dengan upah per hari sebesar Rp 50.000/orang. Dalam perontokkan ini mesin rontok disewa dengan cara, 10 karung gabah maka 1 karung gabahnya untuk pemilik rontok sebagai biaya sewa untuk rontok.

\section{○ Pasca Panen}

\section{Pengangkutan}

Kegiatan pengangkutan umumnya menggunakan alat bantu transportasi seperti tenaga kerja (orang), truk, dan pick up (mobil). Gabah yang siap diangkut terlebih dahulu dikemas dalam karung yang berukuran $50 \mathrm{~kg}$. Kegiatan pengangkutan biasanya menggunakan truk atau pick up bagi petani yang lahannya jauh dari tempat tinggal dengan nilai sewa sebesar Rp 50.000-250.000 satu kali jalan. Sedangkan kegiatan pengangkutan yang lahannya dekat dengan tempat tinggal menggunakan tenaga manusia.

\section{Pengeringan}

Proses pengeringan yang dilakukan di Desa Manleten Kecamatan Tasifeto Timur Kabupaten Belu dengan cara di jemur selama 1-2 hari, dilihat dari intensitas sinar matahari. Tujuan dari proses pengeringan adalah untuk mencegah kerusakan pada waktu penyimpanan serta menjaga agar beras yang dihasilkan pada saat proses penggilingan bulirnya tidak hancur atau patah-patah.

\section{Penggilingan}

Penggilingan yaitu kegiatan memisahkan kulit gabah dari isinya kegiatan penggilingan tersebut dilakukan ketika petani responden ingin menjual atau untuk kebutuhan konsumsi dengan tidak mengeluarkan uang tunai tetapi dengan sistem tidak membawa dedak.

\section{Pemasaran}

Hasil produksi usahatani padi sawah di Desa Manleten Kecamatan Tasifeto Timur Kabupaten Belu yang di jual oleh petani responden di toko, kios dan kepada tetangga terdekat dengan menggunakan transportasi motor, ojek dan mobil pick up dan bisa juga ditimbang di rumah oleh pembeli dengan harga beras Rp 10.000-11.000/kg.

\section{Produksi Padi Sawah}

Besar kecilnya pendapatan petani sangat bergantung pada volume produksi. Semakin besar volume produksi yang dihasilkan maka semakin tinggi pula penerimaan yang akan diterima. Produksi padi sawah di Desa Manleten Kecamatan Tasifeto Timur Kabupaten Belu berbentuk gabah kering. Produksi padi sawah berkisar antara $1.800-12.500 \mathrm{~kg}$ dengan rata-rata produksi sebesar $5.652 \mathrm{~kg}$.

Hasil produksi padi sawah yang dikelola sebagian untuk dijadikan sebagai bibit, sebagian dikonsumsi dan sebagian lagi dijual untuk menutupi kebutuhan biaya untuk produksi selanjutnya.

Variasi produksi usahatani padi sawah paling banyak terdapat pada 1.800-5.000 kg dengan luas lahan 24-100 are jumlah responden sebanyak 18 orang dengan persentase sebesar $56,250 \%$. Variasi produksi $5.001-10.000 \mathrm{~kg}$ dengan luas lahan 100-150 are jumlah responden sebanyak 9 orang dengan persentase sebesar $28,125 \%$. Sedangkan variasi produksi padi sawah paling sedikit terdapat pada $10.001-15.000 \mathrm{~kg}$ dengan luas lahan 200 are jumlah responden 5 orang dengan persentase sebesar $15,625 \%$.

\section{Benih}

Benih yang digunakan yaitu benih yang sudah disiapkan oleh petan sebelumnya, tergantung dari luas lahan petani responden, dan jumlah benih yang digunakan dalam usahatani padi sawah berkisar antara $30 \mathrm{~kg}$ sampai dengan 180 $\mathrm{kg}$.Variasi penggunaan benih paling banyak terdapat pada $51 \mathrm{~kg}$ sampai dengan $100 \mathrm{~kg}$ dengan luas lahan 60 are sampai dengan 100 are jumlah responden sebanyak 18 orang dengan persentase sebesar $56,250 \%$, dan variasi penggunaan benih $30 \mathrm{~kg}$ sampai dengan $50 \mathrm{~kg}$ dengan luas lahan 20 are sampai dengan 50 are jumlah responden sebanyak 7 orang dengan persentase sebesar $21,875 \%$. variasi penggunaan benih $101 \mathrm{~kg}$ sampai dengan $150 \mathrm{~kg}$ dengan luas lahan 101 are sampai dengan 150 are jumlah responden 5 orang dengan persentase sebesar $15,625 \%$. Dan variasi penggunaan benih paling sedikit terdapat pada $151 \mathrm{~kg}$ sampai dengan $200 \mathrm{~kg}$ dengan luas lahan 200 are jumlah responden 2 orang dengan persentase sebesar $6,250 \%$.

\section{Konsumsi}

Hasil produksi padi sawah yang dikelola sebahagian digunakan untuk konsumsi. Produksi padi sawah yang digunakan untuk konsumsi bervariasi antara $212-5.190 \mathrm{~kg}$. Variasi konsumsi paling banyak terdapat pada 212-1.000 kg jumlah responden sebanyak 9 orang dengan luas lahan 36-80 are dan persentase sebesar $28,125 \%$. Dan variasi konsumsi paling banyak terdapat pada $1.001-2.000 \mathrm{~kg}$ jumlah responden sebanyak 9 orang dengan luas lahan 20-100 are dan persentase sebesar 28,125\%. Variasi konsumsi terdapat pada 2.001-3.000 kg dengan luas lahan 100-150 are jumlah responden sebanyak 6 orang dengan persentase sebesar $18,750 \%$. Variasi konsumsi terdapat pada 4.001-5.000 kg dengan luas lahan 100-200 are jumlah responden sebanyak 5 orang dengan persentase sebesar $15,625 \%$. Variasi konsumsi terdapat pada 5.001-6.000 kg dengan luas lahan 200 are jumlah responden 2 orang dengan persentase sebesar $6,250 \%$. dan variasi konsumsi paling sedikit terdapat pada 3.001-4.000 kg dengan luas lahan 100 are jumlah responden 1 orang dengan persentase sebesar $3,125 \%$.

\section{Jual}

Hasil produksi padi sawah yang dikelola sebahagian petani ada yang digunakan untuk jual dan ada juga yang tidak melakukan penjualan. Petani responden biasanya menjual hasil panennya dalam bentuk beras dengan harga Rp 10.000-11.000/kg. Produksi padi sawah yang digunakan untuk jual bervariasi antara $500-7.500 \mathrm{~kg}$. Variasi jual paling banyak terdapat pada 2.001-3.000 kg jumlah responden 13 orang dengan luas lahan 60-150 are dan persentase sebesar $40,625 \%$. Variasi jual paling sedikit terdapat pada $500-1.000$ $\mathrm{kg}$ jumlah responden 2 orang dengan luas lahan 20-24 are dan persentase sebesar $6,25 \%$. Dan variasi jual paling sedikit terdapat pada $3.001-4.000 \mathrm{~kg}$ jumlah responden 2 orang dengan luas lahan 100 are dan persentasenya $6,25 \%$.

\section{Sewa rontok}

Petani yang tidak memiliki rontok menyewa rontok dengan gabah sebagai biaya sewa rontok. bila petani memiliki gabah 10 karung maka biaya sewa rontok 1 karung. Produksi padi sawah yang digunakan untuk rontok bervariasi antara $100-1.150 \mathrm{~kg}$. Variasi sewa rontok paling banyak terdapat pada $200-1.000 \mathrm{~kg}$ dengan luas lahan 20-150 are jumlah responden 13 orang dengan persentase sebesar $86,667 \%$. Dan variasi sewa rontok paling sedikit terdapat pada $1.001-$ $2.000 \mathrm{~kg}$ dengan luas lahan 200 are jumlah responden 2 orang dengan persentase sebesar $13,333 \%$

\section{Beras}

Petani di desa manleten kecamatan tasifeto timur kabupaten belu biasanya tidak menjual gabah tetapi mereka menjualnya dalam beras. Produksi padi sawah yang digunakan bervariasi antara $250-4.050 \mathrm{~kg}$. Variasi jual beras paling banyak terdapat pada 1.001-2.000 kg dengan luas lahan 36-150 are jumlah responden 20 orang dengan persentase sebesar $62,5 \%$. Dan variasi jual beras paling sedikit terdapat pada 4.001-5.000 $\mathrm{kg}$ dengan luas lahan 200 are jumlah responden sebanyak 1 orang dengan persentase sebesar $3,125 \%$.

\section{Biaya Produksi Usahatani Padi Sawah}

Biaya produksi adalah korbanan yang harus dikeluarkan oleh petani untuk memperoleh faktor-faktor penunjang lainnya bagi jalannya proses produksi usahatani padi sawah. biaya usahatani yang diamati dalam penelitian ini meliputi : biaya pengadaan bibit, biaya pengadaan pupuk, biaya pengadaan pestisida, biaya pengadaan tenaga kerja, biaya penyusutan alat, biaya pajak atas tanah, dan biaya transportasi.

\section{Biaya Pengadaan Bibit}

Berdasarkan hasil penelitian menunjukkan bahwa biaya bibit tidak diperhitungkan karena bibit sudah disiapkan oleh petani sebelumnya, tergantung dari luas lahan petani responden, dan jumlah bibit yang digunakan dalam usahatani padi sawah sudah disiapkan para petani responden setelah panen raya untuk dijadikan bibit menurut luas lahan petani responden.

\section{Biaya Pengadaan Pupuk}

Dalam usahatani padi sawah biaya pupuk di perhitungkan karena pupuk digunakannya. Pupuk yang digunakan yaitu pupuk yang disesuaikan dengan lahan pada pertumbuhan padi sawah.

Tabel 7. Variasi Biaya Penggunaan Pupuk Usahatani Padi Sawah di Desa Manleten

\begin{tabular}{ccc}
\hline Variasi biaya pupuk (Rp) & Jumlah responden (orang) & Persentase \% \\
\hline $120.000-500.000$ & 11 & 34,375 \\
$500.100-1.000 .000$ & 12 & 37,5 \\
$1.000 .100-1.500 .000$ & 9 & 28,125 \\
\hline Jumlah & 32 & 100 \\
\hline
\end{tabular}

Berdasarkan Tabel 7. dapat diketahui bahwa paling banyak responden mengeluarkan biaya pengadaan pupuk sebesar Rp 500.100-1.000.000 yaitu 12 orang dengan persentase $37,5 \%$. Sedangkan biaya pupuk sebesar Rp $120.000-$ 500.000 sebanyak 11 orang dengan persentase $34,375 \%$. Biaya pengadaan pupuk sebesar Rp 1.000.100-1.500.000 sebanyak 9 orang dengan persentase $28,125 \%$.

\section{Biaya Pestisida}

Penggunaan pestisida bervariasi antara 2 botol/bungkus sampai dengan 10 botol/bungkus, dengan rata-rata penggunaan pestisida 5 botol/ bungkus. Jumlah pestisida akan menentukan besarnya biaya pestisida, setelah dikalikan dengan harga pestisida. Biaya pengadaan pestisida bervariasi antara responden dengan kisaran $\mathrm{Rp}$ 50.000-316.000 dengan rata-rata $\mathrm{Rp}$ 156,688.

Berdasarkan Tabel 8. dapat dijelaskan bahwa paling banyak responden mengeluarkan biaya pengadaan pestisida sebesar Rp 100.100-200.000 sebanyak 20 responden dengan persentase $62,5 \%$ sedangkan paling sedikit biaya 
penggunaan pestisida sebesar Rp 301.000-400.000 sebanyak 1 respoden dengan persentase $3,125 \%$.

Tabel 8. Variasi Biaya Pestisida Usahatani Padi Sawah di Desa Manleten

\begin{tabular}{ccc}
\hline $\begin{array}{c}\text { Variasi biaya penggunaan pestisida } \\
(\mathrm{Rp})\end{array}$ & $\begin{array}{c}\text { Jumlah responden } \\
\text { (orang) }\end{array}$ & $\begin{array}{c}\text { Persentase } \\
(\%)\end{array}$ \\
\hline $50.000-100.000$ & 6 & 18,75 \\
$100.100-200.000$ & 20 & 62,5 \\
$200.100-300.000$ & 5 & 15,625 \\
$301.000-400.000$ & 1 & 3,125 \\
\hline Jumlah & 32 & 100
\end{tabular}

\section{Biaya Tenaga Kerja}

Tenaga kerja dilokasi penelitian berasal dari tenaga kerja dalam keluarga yang merupakan sumbangan dalam keluarga pada produksi secara keseluruhan dan tidak pernah di nilai dengan uang (upah tenaga kerja). sedangkan tenaga kerja luar keluarga dengan biaya perhari sebesar $\mathrm{Rp}$ 50.000/hari.

Tabel 9. Variasi Biaya Tenaga Kerja Usahatani Padi Sawah di Desa Manleten Variasi biaya penggunaan tenaga kerja Jumlah responden Persentase

\begin{tabular}{ccc}
$(\mathrm{Rp})$ & (orang) & $(\%)$ \\
\hline $1.100 .000-5.000 .000$ & 10 & 31,250 \\
$5.000 .100-10.000 .000$ & 19 & 59,375 \\
$10.000 .100-15.000 .000$ & 3 & 9,375 \\
\hline Jumlah & 32 & 100 \\
\hline
\end{tabular}

Berdasarkan Tabel 9. dapat diketahui bahwa biaya penggunaan tenaga kerja paling banyak terdapat pada Rp 5.000.100-10.000.000 sebanyak 19 orang dengan persentase $59,375 \%$. Biaya penggunaan tenaga kerja Rp 1.100.000-5.000.000 sebanyak 10 orang dengan persentase $31,1250 \%$. Sedangkan biaya penggunaan tenaga kerja paling sedikit terdapat pada Rp 10.000.100-15.000.000 sebanyak 3 orang dengan persentase $9,375 \%$.

\section{Biaya Transportasi}

Penggunaan biaya transportasi diperhitungkan dalam usahatani padi sawah dikarenakan dalam rangka pengadaan pupuk, obat-obatan, bensin, solar dan pengangkutan hasil panen produksi padi sawah menggunakan transportasi. Bahwa biaya transportasi dengan jumlah $\mathrm{Rp} 4.450 .000$ dengan rata-rata Rp 139.063.

\section{Biaya Pajak}

Biaya pajak merupakan biaya tetap yang tidak dipengaruhi oleh besar kecilnya produksi. Biaya pajak yang dikeluarkan tergantung dari luas lahan. Biaya pajak terbesar $\mathrm{Rp} 105.000$ dan terendah $\mathrm{Rp} 12.000$ dengan rata-rata biaya pajak Rp 49.954.

\section{Biaya Penyusutan Alat}

Biaya penyusutan alat merupakan alat-alat yang digunakan hanya untuk usahatani padi sawah atau usahatani itu sendiri. Biaya-biaya penyusutan alat meliputi cangkul, parang, traktor, ember, mesin rontok, karung, sabit, tali rafia, terpal, jarum, hand sprayer. Jumlah total biaya penyusutan sebesar $\mathrm{Rp} 424.531 .892$ dengan rata-rata total biaya penyusutan sebesar Rp 13.266.622.

\section{Penerimaan Usahatani Padi Sawah}

Penerimaan diperoleh dari harga dikalikan dengan jumlah yang dijual. Masyarakat yang ada di Desa Manleten Kecamatan Tasifeto Timur Kabupaten Belu melakukan penjualan dalam bentuk beras, biasanya mereka menjual beras kepada tetangga, kios, dan toko. Beras yang dijual biasanya dengan harga Rp $10.000-11.000 / \mathrm{kg}$

Tabel 10. Variasi Penerimaan Usahatani Padi Sawah di Desa Manleten

\begin{tabular}{ccc}
\hline $\begin{array}{c}\text { Variasi penerimaan } \\
(\mathrm{Rp})\end{array}$ & $\begin{array}{c}\text { Jumlah resp } \\
\text { (orang) }\end{array}$ & $\begin{array}{c}\text { Persentase } \\
\%\end{array}$ \\
\hline $2.500 .000-10.000 .000$ & 7 & 21,875 \\
$10.050 .000-20.000 .000$ & 20 & 62,5 \\
$20.050 .000-30.000 .000$ & 3 & 9,375 \\
$30.050 .000->40.000 .000$ & 2 & 6,25 \\
\hline Jumlah & 32 & 100 \\
\hline
\end{tabular}

Berdasarkan Tabel 10. dapat dijelaskan bahwa variasi penerimaan paling banyak terdapat pada Rp 10.050.000-20.000.000 sebanyak 20 orang dengan persentase 62,5\%. Variasi penerimaan $\mathrm{Rp} 2.500 .000-10.000 .000$ sebanyak 7 orang dengan persentase $21,875 \%$. Variasi penerimaan Rp 20.050.000-30.000.000 sebanyak 3 orang dengan persentase $9,375 \%$. Sedangkan variasi penerimaan paling sedikit terdapat pada Rp 30.050.000->40.000.000 sebanyak 2 orang dengan persentase $6,25 \%$.

\section{Pendapatan Usahatani Padi Sawah}

Variasi pendapatan paling banyak terdapat pada Rp 0-1.084.333 sebanyak 18 orang dengan persentase 56,25\%. Variasi pendapatan Rp 1.084.334-5.000.000 sebanyak 8 orang dengan persentase $25 \%$. Variasi pendapatan Rp 5.000.001-10.000.000 sebanyak 5 orang dengan persentase $15,625 \%$. Sedangkan variasi pendapatan paling sedikit terdapat pada Rp 10.000.001-20.000.000 sebanyak 1 orang dengan persentase 3,125\%. Hal ini dapat dilihat pada Tabel 11 .

Tabel 11. Variasi Pendapatan Usahatani Padi Sawah di Desa Manleten

\begin{tabular}{ccc}
\hline Variasi pendapatan $(\mathrm{kg})$ & Jumlah responden (orang) & Persentase $(\%)$ \\
\hline $0-1.084 .333$ & 18 & 56,25 \\
$1.084 .334-5.000 .000$ & 8 & 25 \\
$5.000 .001-10.000 .000$ & 5 & 15,625 \\
$10.000 .001-20.000 .000$ & 1 & 3,125 \\
\hline Jumlah & 32 & 100 \\
\hline
\end{tabular}

\section{Simpulan} berikut:

Berdasarkan hasil dan pembahasan maka dapat disimpulkan sebagai

1. Aktivitas usahatani padi sawah pada umumnya adalah persemaian (penggunaan bibit, pengolahan lahan calon persemaian, penaburan benih, dan pemeliharaan persemaian) Persiapan dan pengolahan lahan sawah (pembersihan lahan, pembajakan dan penggaruan) Penanamann, pemeliharaan (penyulaman, penyiangan gulma, pengairan, pengendalian pestisida, dan pemupukan), panen (perontokkan), pasca panen (pengangkutan, pengeringan, penggilingan).

2. Pendapatan petani dari usahatani padi sawah di Desa Manleten Kecamatan Tasifeto Timur Kabupaten Belu yaitu dengan total pendapatan dari 32 responden petani padi sawah berkisar antara $\mathrm{Rp} 1.820 .667-113.774 .000$ dengan rata-rata pendapatan sebesar $\mathrm{Rp}$ 45.192.524.

Pustaka

Dinas Pertanian. 2016. Dinas Tanaman Pangan, Hortikultura dan Perkebunan Kab. Belu. Atambua.

Mubyarto. 2003. Pengantar Ekonomi Pertanian. LP3ES. Jakarta

Nurmanaf. 2003. Karakteristik Rumah tangga Petani Berlahan Sempit: Struktur dan Stabilitas Pendapatan di Wilayah Berbasis Lahan Sawah Tadah Hujan (Kasus di Propinsi Jawa Tengah dan Jawa Timur). J. SOCA Vol. 3 No. 2. Juli 2003: $181-187$

Soekartawi. 1983. Ilmu Usahatani dan Penelitian Untuk Mengembangkan Petani Kecil. Jakarta: UI-Press.

Soekartawi. 1995. Analisis Usahatani. Jakarta: UI- Press.

Soekartawi. 2006. Analisis Usahatani. Universitas Indonesia. Jakarta

Sudarsono. 2008. Pengantar Ekonomi Mikro. LP3ES. Jakarta

Sukirno, S. 2005. Pengantar Teori Mikro Ekonomi. Raja Grafindo Persada. Jakarta. 